\title{
EFFECTS OF SOYBEAN PHOSPHATIDES ON THE HEMORRHAGIC TENDENCY DUE TO THROMBOCYTOPENIA *
}

\author{
By ISAAC DJERASSI, SIDNEY FARBER, ALBERT J. ROY AND \\ HIROKU YOSHIMURA \\ (From The Children's Cancer Research Foundation and the Department of Pathology, \\ Children's Hospital Medical Center and Harvard Medical School, \\ Boston, Mass.)
}

(Submitted for publication August 31, 1961 ; accepted November 30, 1961)

Thrombocytopenia or qualitative platelet deficiencies result in disturbed coagulation and clot retraction, prolonged bleeding from sites of minor injury, decreased vascular resistance, and increased permeability of blood and lymph vessels to red blood cells. It is not known whether control of any one of these defects alone might modify the incidence or the severity of thrombocytopenic bleeding. Studies of the individual disturbances resulting from platelet deficiency may, however, contribute to the understanding of the mechanisms of hemostasis and of maintenance of vascular integrity.

The studies presented here are concerned with one of the above manifestations of the hemorrhagic tendency of thrombocytopenia; namely, the escape of red blood cells into the lymph of thrombocytopenic animals. Bigelow, Furth, Woods and Storey (1), in agreement with previous work by Drinker and Yoffey (2), have indicated that red blood cells reach the lymph channels in the absence of gross morphologic or microscopic changes of the walls of blood vessels. The abnormally high concentration of red blood cells in the lymph of thrombocytopenic animals therefore results from an increase in the permeability of blood and lymph vessels to formed blood elements. This aspect of the hemorrhagic tendency in thrombocytopenia has been studied previously in relation to the hemostatic activities of fresh platelets and of preserved platelet material $(3,4)$.

White, Lagen, Aggeler and Geyer demonstrated that the administration of soybean phosphatides to X-irradiated, thrombocytopenic dogs results in a temporary improvement of the coagulation defects (5). The effects of a similar preparation on the output of red blood cells in the lymph of X-

* This investigation was supported by Grant AT (301) 1793 from the Atomic Energy Commission. irradiated, thrombocytopenic dogs are the subject of this report.

\section{METHODS AND MATERIALS}

Healthy mongrel dogs were rendered thrombocytopenic by exposure to $470 \mathrm{r}$ whole body $\mathrm{X}$-irradiation, given in 2 doses of $235 \mathrm{r}$ delivered to each side of the body. A $250 \mathrm{kv}, 15 \mathrm{ma} \mathrm{X}$-ray source ${ }^{1}$ was used with $0.25 \mathrm{~mm}$ copper and $1.0 \mathrm{~mm}$ aluminum filters. The source-target (mid-body level) distance was $110 \mathrm{~cm}$ and the rate of irradiation was $5.2 \mathrm{r}$ per minute at the skin surface as determined with a Victoreen dosimeter. The animals were anesthetized ( $40 \mathrm{mg}$ pentobarbital per $\mathrm{kg}$ ) throughout the exposure to $\mathrm{X}$-ray.

Cannulation of the thoracic lymph duct was carried out 5 to 7 days after $\mathrm{X}$-irradiation, as described previously (6). The lymph flow from the left thoracic lymph duct to the left external jugular vein was restored by connecting the corresponding plastic cannulae with an exteriorized loop of tubing which was secured with wound clips. Recognition of the optimal time for further study was thus facilitated by the visualization of grossly bloody lymph in the exteriorized loop of tubing. In most instances this occurred 9 to 11 days after irradiation and was invariably associated with marked thrombocytopenia. At this time the animals were anesthetized again and the output of red blood cells in the lymph was determined at regular intervals. Mean arterial blood pressure measurements were carried out with a mercury manometer by cannulation of the right femoral artery. The total output of red blood cells in the lymph per unit of time was determined by disconnecting the lymph duct and the external jugular vein cannulae and collecting the lymph for periods of 5 minutes in $2 \mathrm{ml}$ of a 3.8 per cent solution of sodium citrate. Unless stated otherwise, collection of lymph was repeated every 15 minutes, the flow of lymph into the venous circulation being restored during the intervals. The total output of red blood cells per minute was calculated as follows: total output per minute $=$ ( $\mathrm{RBC}$ per $\mathrm{mm}^{3} \times 1,000 \times$ milliliters of lymph collected) /5. Platelet counts were carried out under phase-contrast microscopy (7). Prothrombin consumption was measured by determination of residual prothrombin in serum by a modification of Owren's procedure (8) after incu-

\footnotetext{
1 General Electric, model Maximar 250-3.
} 
TABLE I

.Effect of saline on total output of red blood cells in the thoracic duct lymph of thrombocytopenic dogs *

\begin{tabular}{|c|c|c|c|c|c|c|c|}
\hline \multirow[b]{2}{*}{ Dog no. } & \multicolumn{3}{|c|}{ Before treatment } & \multirow{2}{*}{$\begin{array}{c}\text { At time of } \\
\text { treatment } \\
\quad 0\end{array}$} & \multicolumn{3}{|c|}{ After treatment } \\
\hline & $60 \mathrm{~min}$ & $40 \mathrm{~min}$ & $20 \min$ & & $20 \mathrm{~min}$ & $40 \mathrm{~min}$ & $60 \mathrm{~min}$ \\
\hline $\begin{array}{l}257 \mathrm{~B} \\
257 \mathrm{~A} \\
255 \mathrm{~A} \\
255 \mathrm{~B} \\
254 \\
249 \\
117 \\
150 \\
261 \mathrm{~A} \\
263 \\
\text { Mean }\end{array}$ & $\begin{array}{l}2.81 \\
2.57 \\
3.02 \\
3.33 \\
3.02 \\
4.03 \\
2.75 \\
3.10 \\
2.94 \\
2.76 \\
3.03\end{array}$ & $\begin{array}{l}2.84 \\
2.72 \\
3.12 \\
3.35 \\
2.82 \\
4.08 \\
2.74 \\
3.31 \\
2.82 \\
2.85 \\
3.07\end{array}$ & $\begin{array}{l}2.82 \\
2.88 \\
3.22 \\
3.33 \\
2.99 \\
4.13 \\
2.99 \\
3.30 \\
2.92 \\
2.80 \\
3.14\end{array}$ & $\begin{array}{l}2.97 \\
2.84 \\
3.33 \\
3.17 \\
2.89 \\
4.10 \\
3.38 \\
3.35 \\
2.64 \\
2.81 \\
3.16\end{array}$ & $\begin{array}{l}2.96 \\
2.59 \\
3.22 \\
3.17 \\
3.05 \\
3.99 \\
3.30 \\
3.19 \\
2.59 \\
2.99 \\
3.11\end{array}$ & $\begin{array}{l}3.22 \\
2.67 \\
3.00 \\
3.15 \\
3.12 \\
4.19 \\
3.63 \\
3.54 \\
2.67 \\
2.96 \\
3.22\end{array}$ & $\begin{array}{l}3.30 \\
2.50 \\
3.03 \\
3.14 \\
2.84 \\
4.13 \\
3.49 \\
3.61 \\
3.09 \\
2.97 \\
3.21\end{array}$ \\
\hline
\end{tabular}

${ }^{*}$ Logarithm of total $\mathrm{RBC}$ count in lymph collected during 1 minute.

bation of $2 \mathrm{ml}$ of clotted blood for 1 hour at $37^{\circ} \mathrm{C}$. Bleeding time was determined by incision ( 4 to $5 \mathrm{~mm}$ long and about $1 \mathrm{~mm}$ deep) of the external surface of the ear. Care was taken to avoid areas with visible large blood vessels. The preparation of soybean phosphatides (SBP) ${ }^{2}$ used in these studies was homogenized in saline $(2 \mathrm{~g}$ per $100 \mathrm{ml})$ and administered intravenously by gravity ( 40 to 60 drops per minute). The dose of phosphatides was $200 \mathrm{mg}$ per $\mathrm{kg}$ body weight per infusion. Control animals received equivalent volumes of physiological saline.

As recommended previously $(3,4)$, a period of equilibration was allowed in order to permit stabilization of the output of red blood cells in the lymph prior to the administration of saline or SBP, respectively. This period was usually 120 to 240 minutes. Saline or phosphatides were not administered when the immediately preceding observations showed a decline of total output of red blood cells.

\section{RESULTS}

\section{Control studies}

In the control group of 10 thrombocytopenic dogs the average output of red blood cells in the lymph after administration of physiological saline continued at a markedly elevated level (Figure 1). Individual control animals, however, showed considerable variations (Table I). The elevated bleeding time (more than 30 minutes) and the defective prothrombin consumption indicated by serum prothrombin times of 12 to 16 seconds (normal, in excess of 35 seconds) remained unchanged following the administration of saline.

${ }^{2}$ RG-Lecithin, The Glidden Company, Chicago, Ill.

\section{Studies on infusions of soybean phosphatides}

A group of 12 thrombocytopenic dogs received soybean phosphatides. The serum prothrombin time determined prior to and 1 hour after infusion of SBP increased in Dogs 18 and 26 from 10 and 12 seconds to 57 and 86 seconds, respectively. In Dogs 34 and 36, however, the serum prothrombin time remained essentially unchanged (11 and 12 seconds). The bleeding time in all animals remained prolonged (more than $30 \mathrm{~min}$ utes as compared to 3 to 8 minutes in normal dogs). The observations on the output of red cells in the lymph are included in Table II and Figure 1. Figure 1 shows the mean values of Table II for this group and for the control group (Table I) in terms of total output of red blood cells in the lymph per minute. In order to attain uniformity of data for all animals, the summary data are limited to the 60 -minute periods preceding and immediately following the administration of SBP or saline. In the experiments in which multiple infusions were given, only the first infusion was included in the statistical analysis. It will be noted that in both groups the output of red cells at the time of initiation of treatment and 20 minutes previously is slightly higher than the general trend. This is in keeping with the experimental design, according to which the agent under study was administered when the total output of red blood cells was steady, or rising. In order to eliminate a possible selective effect of this procedure, the observations at the time of initiation of treatment and 20 minutes 


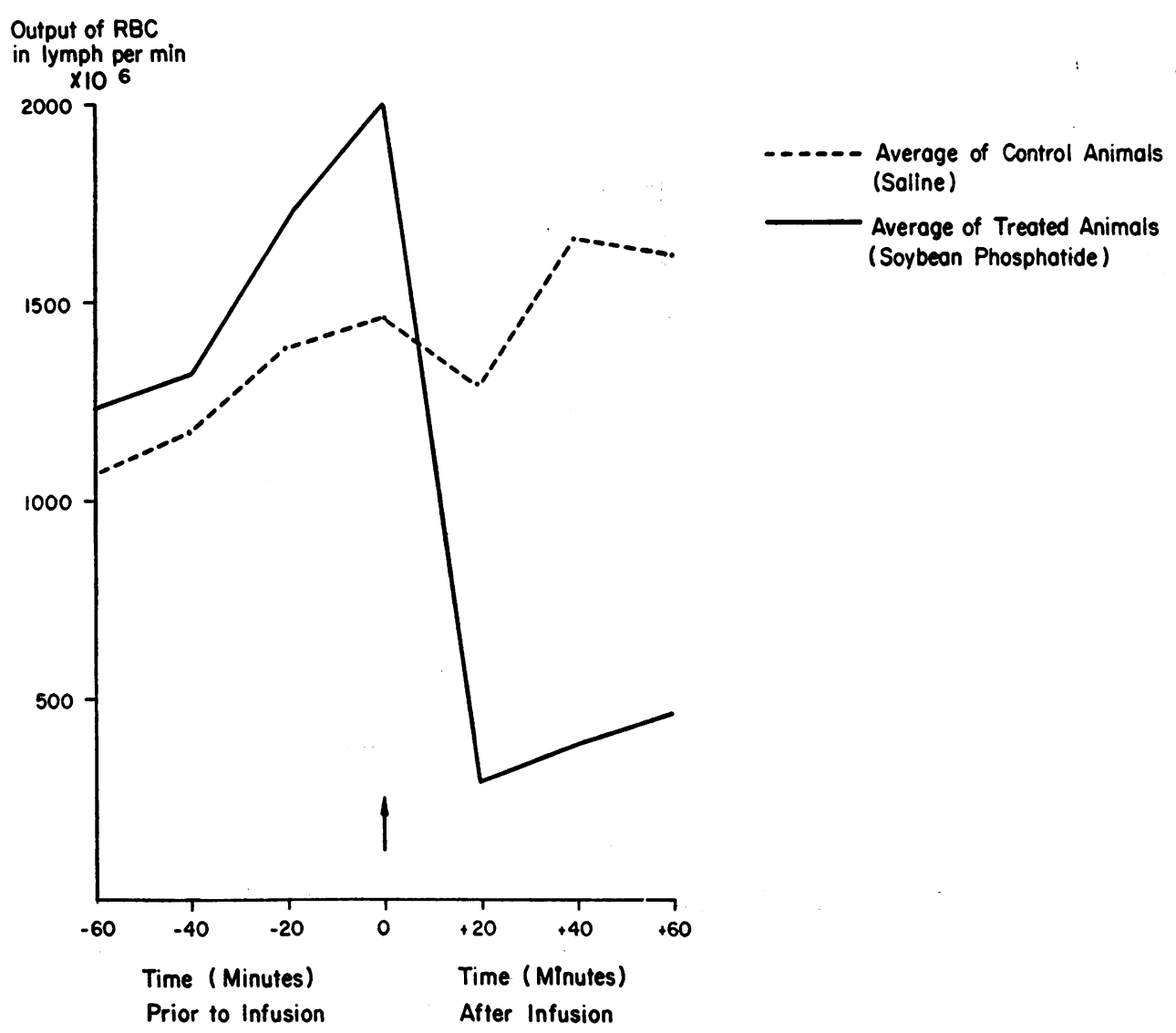

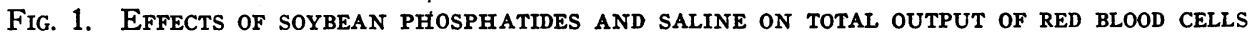
IN THE LYMPH OF THROMBOCYTOPENIC, X-IRRADIATED DOGS.

before and after treatment were eliminated from the statistical analysis. As can be seen from the data, the inclusion of these three points would have increased further the difference between the treated and the control groups.
Comparison of the determinations 40 and 60 minutes before with those 40 and 60 minutes after infusion showed a sharp decrease of the output of red blood cells in the phosphatide-treated animals and a moderate increase in the control

TABLE II

Effect of soybean phosphatides on total output of red blood cells in the thoracic duct lymph of thrombocytopenic dogs *

\begin{tabular}{|c|c|c|c|c|c|c|c|c|}
\hline \multirow[b]{2}{*}{ Dog no. } & & \multicolumn{3}{|c|}{ Before treatment } & \multirow{2}{*}{$\begin{array}{c}\text { At time of } \\
\text { treatment } \\
0\end{array}$} & \multicolumn{3}{|c|}{ After treatment } \\
\hline & & $60 \mathrm{~min}$ & $40 \mathrm{~min}$ & $20 \mathrm{~min}$ & & $20 \mathrm{~min}$ & $40 \mathrm{~min}$ & $60 \mathrm{~min}$ \\
\hline $\begin{array}{c}18 \\
22 \\
25 \\
26 \\
34 \\
30 \\
43 \\
55 \\
57 \\
36 \\
\text { Mean }\end{array}$ & & $\begin{array}{l}2.89 \\
2.88 \\
2.78 \\
3.52 \\
3.20 \\
2.87 \\
3.67 \\
3.42 \\
3.08 \\
2.53 \\
3.09\end{array}$ & $\begin{array}{l}3.14 \\
3.03 \\
2.72 \\
3.42 \\
3.45 \\
2.95 \\
3.43 \\
3.33 \\
3.21 \\
2.54 \\
3.12\end{array}$ & $\begin{array}{l}3.28 \\
3.11 \\
2.84 \\
3.65 \\
3.29 \\
3.03 \\
3.56 \\
3.49 \\
3.12 \\
2.81 \\
3.23\end{array}$ & $\begin{array}{l}3.29 \\
3.11 \\
3.01 \\
3.68 \\
3.47 \\
3.00 \\
3.55 \\
3.57 \\
3.31 \\
3.04 \\
3.30\end{array}$ & $\begin{array}{l}1.73 \\
2.37 \\
2.92 \\
2.89 \\
1.15 \\
2.48 \\
2.92 \\
2.59 \\
3.28 \\
2.33 \\
2.47\end{array}$ & $\begin{array}{l}1.93 \\
2.37 \\
2.82 \\
2.59 \\
2.31 \\
2.61 \\
3.00 \\
2.61 \\
3.14 \\
2.49 \\
2.59\end{array}$ & $\begin{array}{l}2.10 \\
2.38 \\
3.04 \\
2.78 \\
2.58 \\
2.63 \\
3.07 \\
2.82 \\
2.86 \\
2.45 \\
2.67\end{array}$ \\
\hline
\end{tabular}

* Logarithm of total RBC count in lymph collected during 1 minute. 


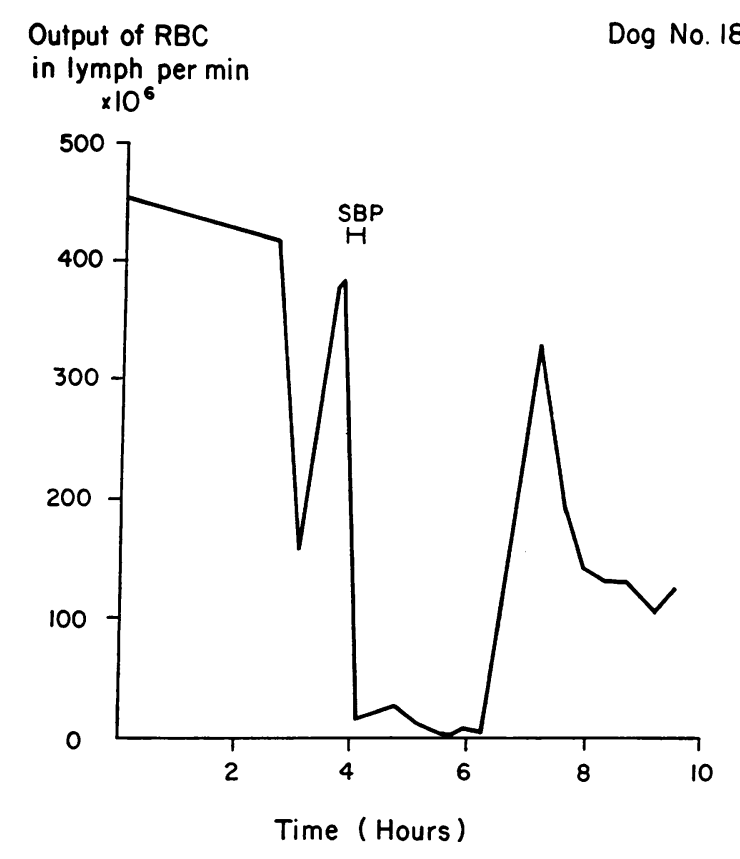

FIG. 2.

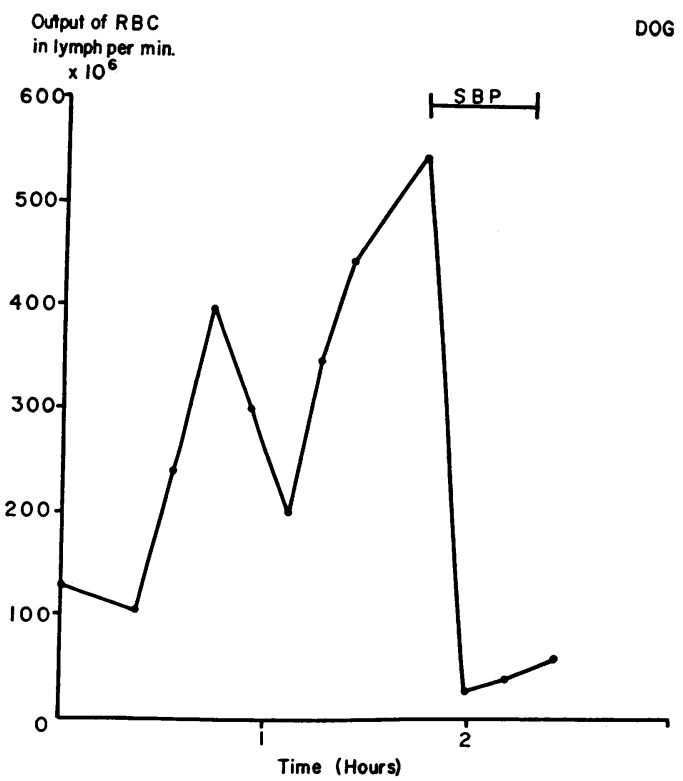

FIG. 3.

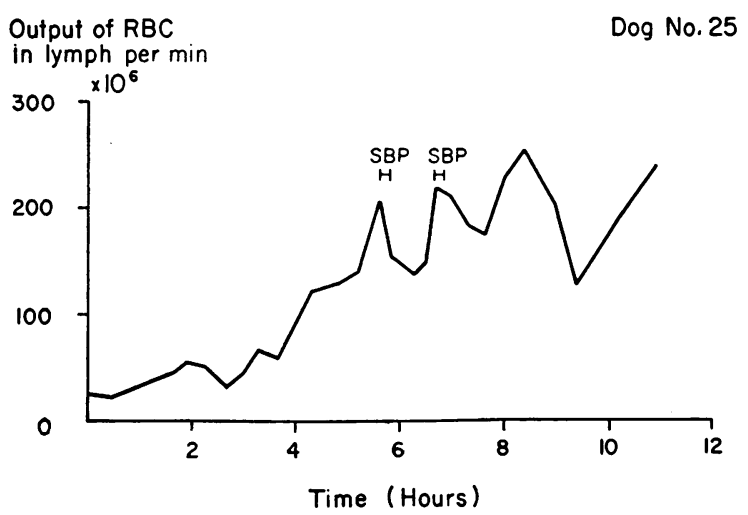

FIG. 4.

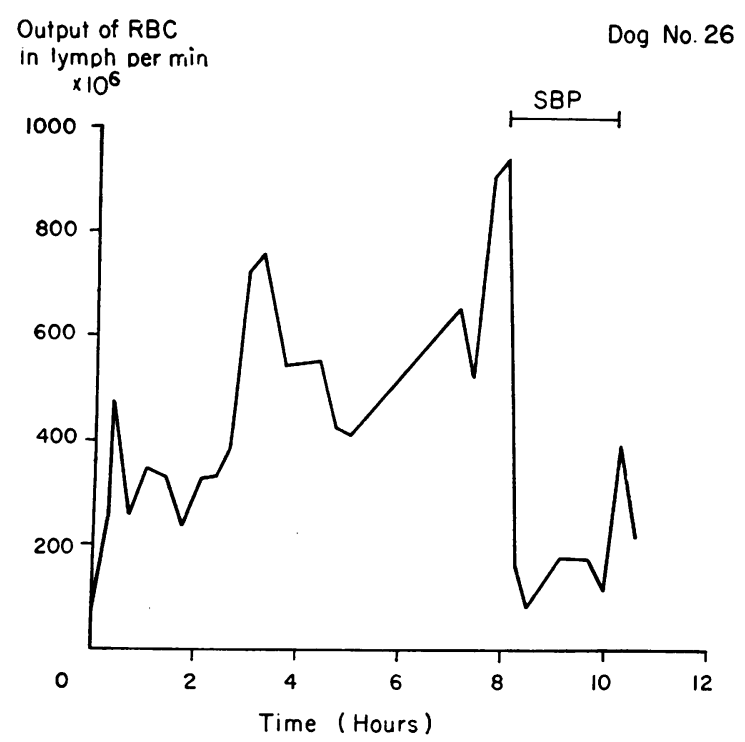

FIG. 5.

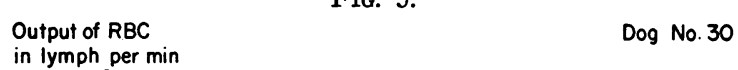

in lymph per min

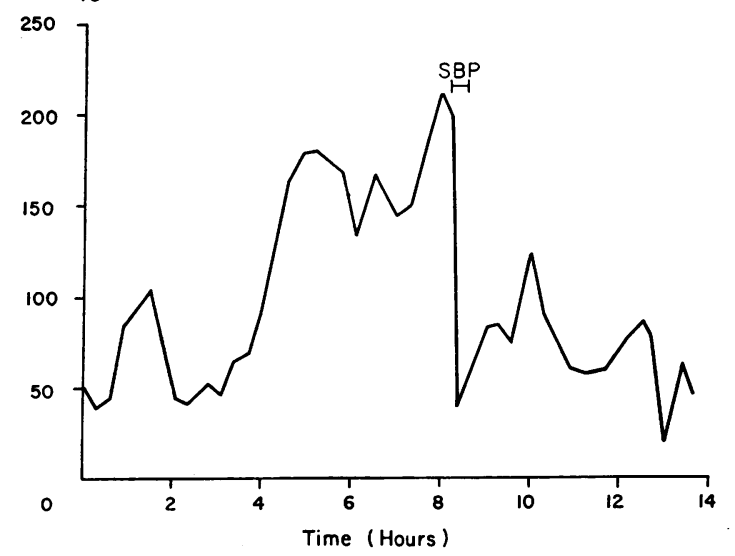

FIG. 6.

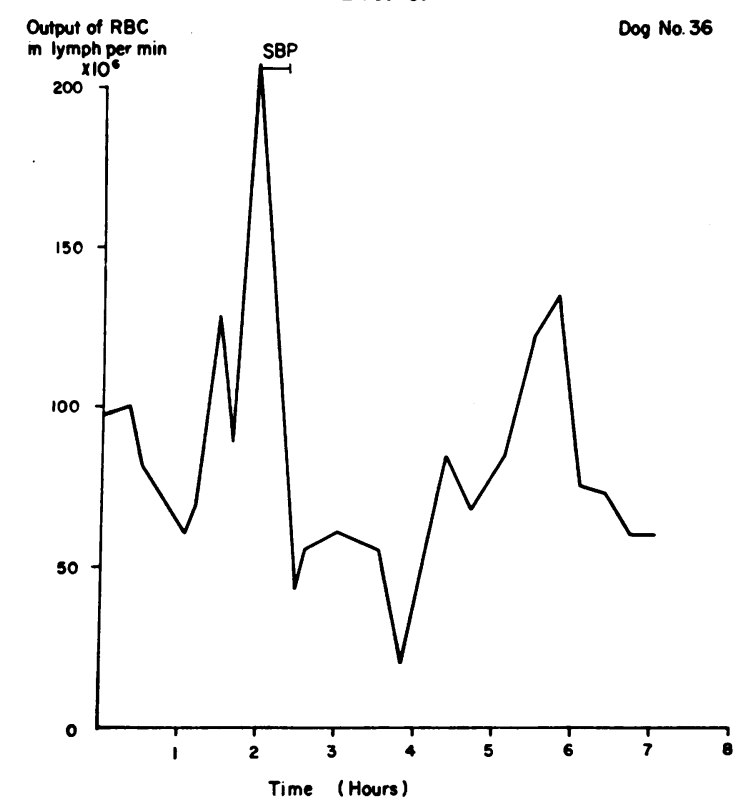

FIG. 7. 

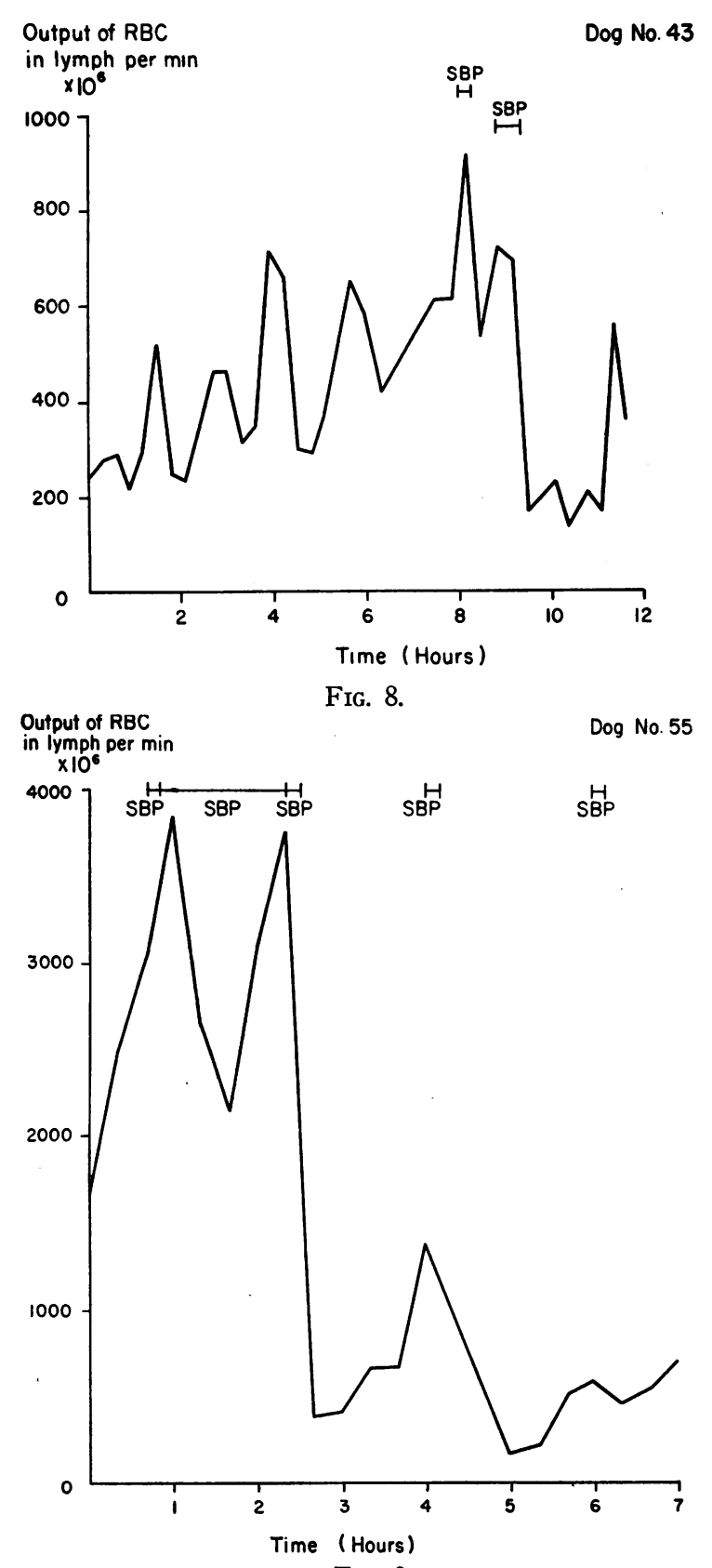

Output of RBC
in lymph per min
$\times 10^{6}$
300

Dog No. 22
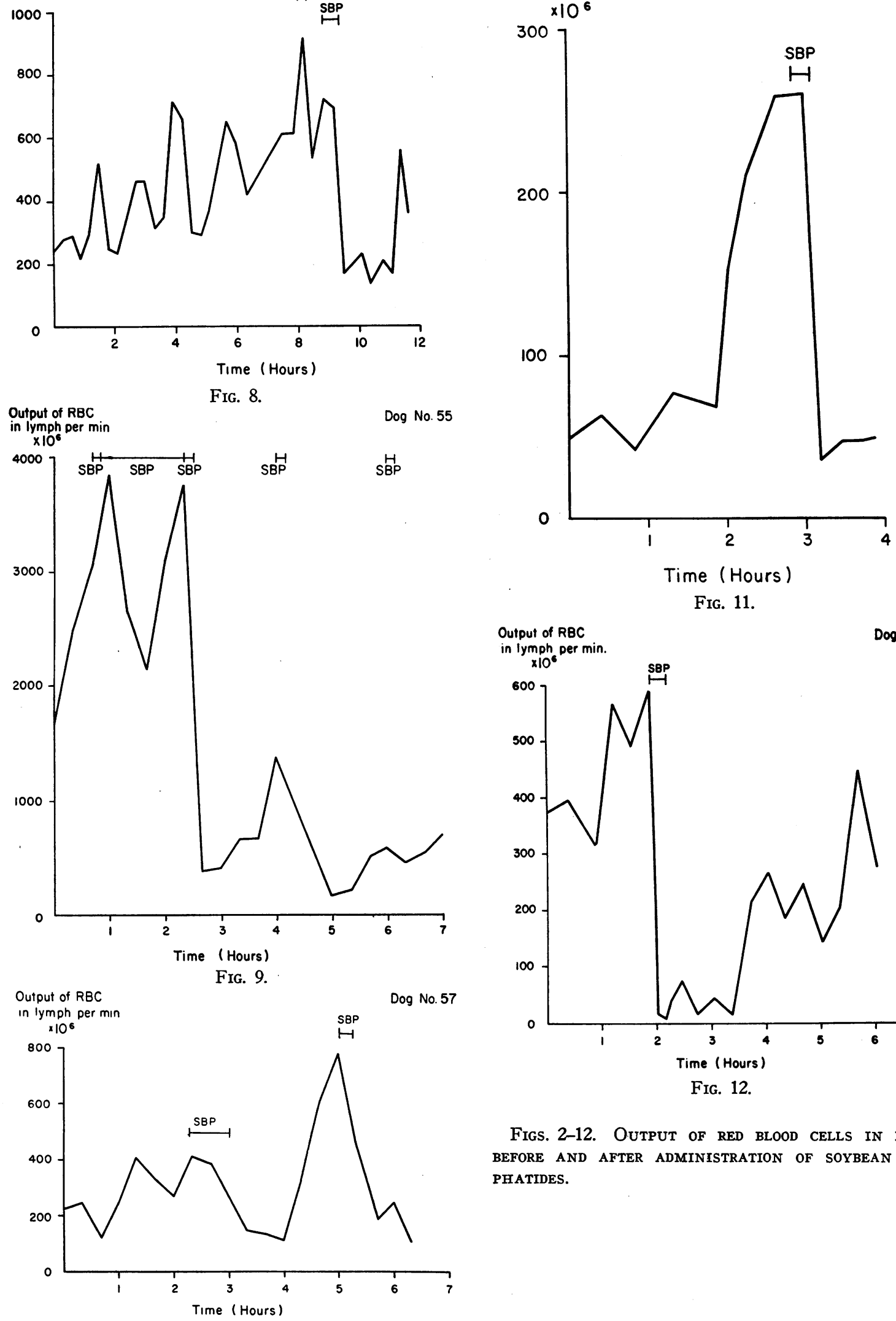

Fig. 11.

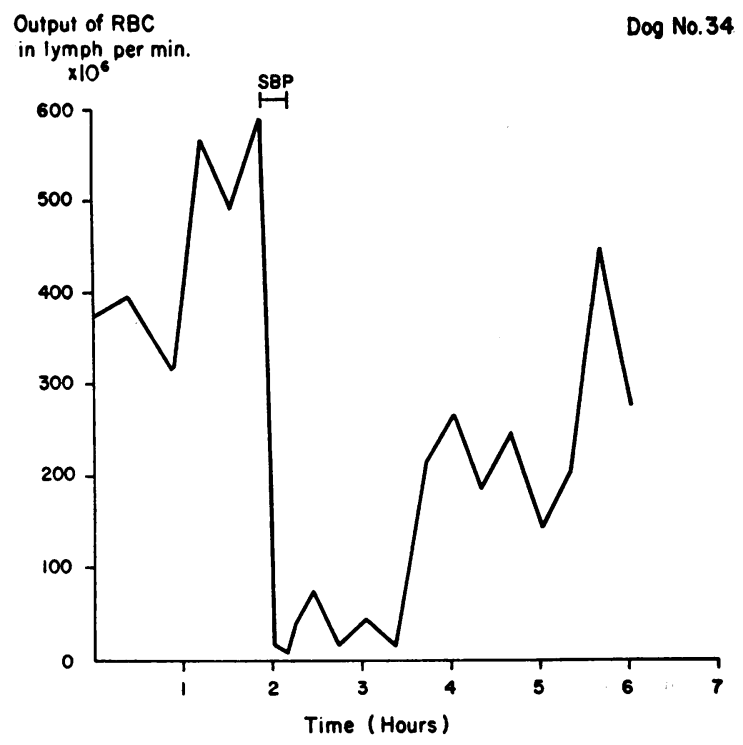

FIG. 12.

Figs. 2-12. OUtPut OF RED bloOd CELls IN LyMPH BEFORE AND AFTER ADMINISTRATION OF SOYBEAN PHOSPHATIDES. 
animals. This difference in the responses of the two groups is statistically significant. ${ }^{3}$ The course of events during each study is described in the following protocols.

\section{Protocols on individual animals (Figures 2-12)}

Dog 18 (Figure 2). The thoracic duct of this $12 \mathrm{~kg}$ female dog was cannulated 8 days after $\mathrm{X}$-irradiation. The initial output of red blood cells in the lymph was $452 \times 10^{6}$ cells per minute. The platelet count was 8,000 per $\mathrm{mm}^{3}$, and the blood pressure was $120 \mathrm{~mm} \mathrm{Hg}$. Six lymph samples were collected over 4 hours. The average flow of lymph during this period was $0.9 \mathrm{ml}$ per minute and the output of red blood cells in the lymph remained relatively constant with the exception of one determination at 185 minutes after the initial count. At the end of the equilibration period the red blood cell output in the lymph was $386 \times 10^{6}$.

A suspension of soybean phosphatides in saline was infused over a period of 25 minutes. A reduction (97 per cent) of the output of red cells in the lymph was observed within 15 minutes. The blood pressure remained stable. The lymph flow was reduced to $0.6 \mathrm{ml}$ per minute. A specimen of lymph collected 90 minutes after the infusion was completely free of red cells (lymph flow of $0.7 \mathrm{ml}$ per minute). One hour later a sudden increase in both red blood cell output and lymph flow (1.3 $\mathrm{ml}$ per minute) was observed. The output of red blood cells then decreased again, and 5.5 hours after the infusion of SBP it was 32 per cent of the pretreatment value. The blood pressure was $115 \mathrm{~mm} \mathrm{Hg}$. The experiment was concluded at this time.

Dog 23 (Figure 3). Cannulation of the thoracic duct of this $13 \mathrm{~kg}$ male dog was carried out 6 days after irradiation, at which time the lymph was found to contain a normal number of red blood cells. Four days later the platelet count was 10,000 per $\mathrm{mm}^{3}$ and the lymph in the exteriorized loop of tubing was grossly hemorrhagic. The dog was anesthetized and nine samples of lymph were collected during the next 105 minutes. The output of red blood cells in the lymph was initially $129 \times 10^{6}$ cells per

\footnotetext{
${ }^{3} \mathrm{p}<0.005$ on the basis of a $t$ test on the logarithms of the total output of red blood cells per minute.
}

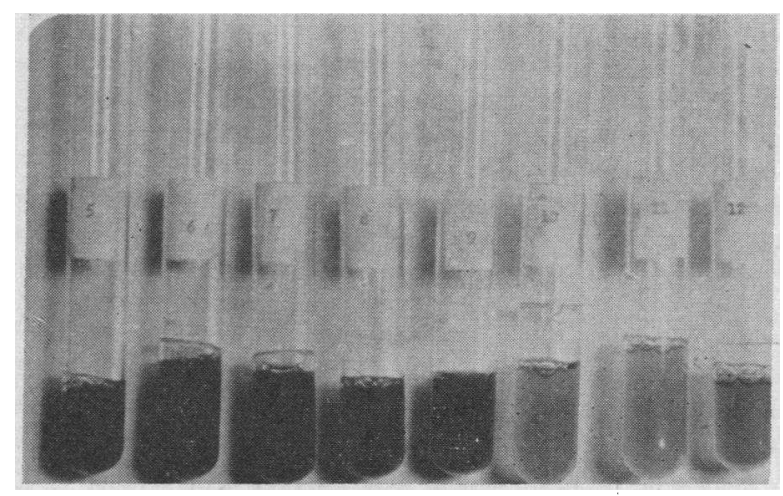

Fig. 13. Appearance of LYMPh BEFoRe AND AFTER INFUSION OF SOYBEAN PHOSPHATIDES (DOG 23). SBP given after tube 9 .

minute and the lymph flow was $0.5 \mathrm{ml}$ per minute. During the equilibration period the red blood cell output increased to $546 \times 10^{6}$ cells per minute. At this time SBP was infused over a period of 30 minutes. Within 20 minutes after the initiation of the infusion the red blood cell output was reduced to $18 \times 10^{6}$ cells per minute (3 per cent of pretreatment value) with a concurrent increase in lymph flow $(0.96 \mathrm{ml}$ per minute). Forty-five minutes after the infusion the output of RBC was 10 per cent of the pretreatment level and the rate of lymph flow was unchanged (Figure 13). The experiment was terminated at this time by an inadvertent administration of an overdose of pentobarbital. Because of the short duration of the observation period, the data on this animal were not suitable for inclusion in the statistical evaluation.

Dog 25 (Figure 4). The thoracic duct of this $12.8 \mathrm{~kg}$ female dog was cannulated 7 days after irradiation. An adequate flow of white normal lymph was observed. The platelet count was 10,000 per $\mathrm{mm}^{3}$. Three days later, when the lymph had turned pink, the dog was reanesthetized and 15 lymph samples were collected during the succeeding 345 minutes. During this time the output of red blood cells in the lymph increased from $24 \times 10^{6}$ to $205 \times 10^{6}$ cells per minute. The average lymph flow was $0.3 \mathrm{ml}$ per minute. The rate of lymph flow remained virtually unchanged throughout the study.

After administration of $200 \mathrm{mg}$ of soybean phosphatides per $\mathrm{kg}$, a slight reduction of the output of red blood cells in the lymph was observed. 
A second infusion of an equal dose of SBP did not significantly alter the appearance or the red blood cell content of the lymph.

Dog 26 (Figure 5). The thoracic duct of this $10 \mathrm{~kg}$ female dog was cannulated 5 days after irradiation. Two days later the platelet count was 34,000 per $\mathrm{mm}^{3}$ and the lymph was grossly bloody. The dog was reanesthetized and 26 samples of lymph were collected over an 8 hour equilibration period during which there was a progressive increase in the total output of red blood cells from $54 \times 10^{6}$ to $944 \times 10^{6}$ cells per minute. The lymph flow averaged $1.0 \mathrm{ml}$ per minute. Twenty minutes and again 35 minutes after the initiation of the infusion of SBP the red cell output in the lymph decreased to 157 $\times 10^{6}$ cells per minute ( -83 per cent) and to $78 \times 10^{6}$ cells per minute ( -92 per cent), respectively. Since only half of the standard dose had been infused by that time, the remaining part was given more slowly. Three hours after the beginning of the infusion the output of red blood cells was 22 per cent of the pretreatment value. The rate of lymph flow did not change significantly throughout the experiment.

Dog 30 (Figure 6). Six days after irradiation of this $9 \mathrm{~kg}$ female dog the thoracic duct was cannulated. The following day the platelet count was 23,000 platelets per $\mathrm{mm}^{3}$ and the lymph was bloody. During the next 8 hours the output of red blood cells in the lymph increased from 52 $\times 10^{6}$ to $210 \times 10^{6}$ cells per minute. The lymph flow averaged $1.5 \mathrm{ml}$ per minute and the mean arterial pressure was $110 \mathrm{~mm} \mathrm{Hg}$. After rapid infusion of soybean phosphatides the output of red blood cells in the lymph was reduced to $39 \times 10^{6}$ cells per minute $(-80$ per cent $)$. This was followed by a gradual increase to $125 \times 10^{6}$ cells per minute and a later decrease to $20 \times 10^{6}$ cells ( -90 per cent). The rate of lymph flow averaged $1.0 \mathrm{ml}$ per minute. The blood pressure at the end of the experiment was $100 \mathrm{~mm} \mathrm{Hg}$.

Dog 36 (Figure 7). This $12.6 \mathrm{~kg}$ male dog was irradiated 6 days prior to cannulation of the thoracic lymph duct. Four days later the platelet count was 14,000 per $\mathrm{mm}^{3}$ and the lymph was grossly bloody. The dog was reanesthetized and 8 lymph samples were collected over a 2-hour period. During this time the output of red blood cells in the lymph increased from $96 \times 10^{6}$ to
$218 \times 10^{6}$ cells per minute. The lymph flow averaged $0.5 \mathrm{ml}$ per minute. Twenty minutes after the infusion of SBP a reduction of the output of red blood cells to $43 \times 10^{6}$ cells per minute occurred. Ninety minutes later the output was $20 \times 10^{6}$ cells per minute ( -91 per cent). The lymph flow during the post-treatment period averaged $1.3 \mathrm{ml}$ per minute.

Dog 43 (Figure 8). The thoracic duct of this $12.2 \mathrm{~kg}$ male dog was cannulated 5 days after irradiation. Four days later the lymph was bloody and the platelet count was 18,000 per $\mathrm{mm}^{3}$. Twenty-five lymph samples were collected over a 7.75 hour period. During this time the output of red blood cells in the lymph increased from $236 \times 10^{6}$ to $612 \times 10^{6}$ cells per minute. The lymph flow averaged $1.3 \mathrm{ml}$ per minute. A total dose of $200 \mathrm{mg}$ of SBP per $\mathrm{kg}$ was given by two separate infusions. The output of red blood cells in the lymph decreased to $168 \times 10^{6}$ cells per minute. With minor variations, this level was maintained for about 2 hours when an abrupt increase to $564 \times 10^{6}$ cells per minute was observed. The lymph flow averaged $1.0 \mathrm{ml}$ per minute during the post-treatment period.

Dog 55 (Figure 9). The thoracic duct of this $11 \mathrm{~kg}$ female dog was cannulated 11 days after irradiation. Grossly bloody lymph was observed. Because of the poor general condition of this dog, only three lymph samples, showing an increase of the output of red blood cells from $1,658 \times 10^{6}$ to $3,040 \times 10^{6}$ cells per minute, were collected prior to administration of SBP. The lymph flow averaged $1.0 \mathrm{ml}$ per minute. SBP suspension was infused rapidly (60 drops per minute) during 15 minutes and then continued at a lower rate (20 drops per minute) for 80 minutes followed by rapid infusion during 10 minutes, thus bringing the total amount of SBP given to $540 \mathrm{mg}$ per $\mathrm{kg}$. Immediately after the infusion a marked decrease in red blood cell output to $390 \times 10^{6}$ cells per minute ( -87 per cent) occurred. This level was maintained for 1 hour and then increased to $1,394 \times 10^{6}$ cells per minute. A second infusion of SBP suspension was followed by a reduction in lymph red blood cell output to $181 \times 10^{6}$ cells per minute. The level rose during the next 2 hours to $692 \times 10^{6}$ cells per minute although a third infusion of SBP had been initiated. Lymph 
flow during the post-treatment period averaged $1.5 \mathrm{ml}$ per minute.

Dog 57 (Figure 10). The thoracic lymph duct of this $11.7 \mathrm{~kg}$ female dog was cannulated 8 days after irradiation. Five days later the platelet count was 26,000 per $\mathrm{mm}^{3}$ and the lymph was hemorrhagic. Eight lymph samples were collected over a 135-minute equilibration period and the output of red blood cells during this time increased from $221 \times 10^{6}$ to $403 \times 10^{6}$ cells per minute. The lymph flow averaged $0.7 \mathrm{ml}$ per minute. A SBP suspension (200 $\mathrm{mg}$ per $\mathrm{kg}$ ) was infused within 40 minutes. A gradual reduction of the red blood cell output to $117 \times 10^{6}$ cells per minute was observed, followed by considerably increased values which reached 774 $\times 10^{6}$ cells per minute within 120 minutes after initiation of the infusion. During the post-treatment period the rate of lymph flow remained essentially unchanged. A second infusion of SBP again resulted in a reduction of the red blood cell level to $104 \times 10^{6}$ cells per minute. The lymph flow rate increased slightly to an average of 1.0 $\mathrm{ml}$ per minute. The blood pressure was $100 \mathrm{~mm}$ $\mathrm{Hg}$ and remained at this level for the duration of the experiment.

Dog 22 (Figure 11). The thoracic duct of this $10.5 \mathrm{~kg}$ female dog was cannulated 6 days after irradiation. The lymph was hemorrhagic on the day of cannulation. The platelet count was 10,000 per $\mathrm{mm}^{3}$. The blood pressure was $110 \mathrm{~mm}$ Hg. Eight lymph samples were collected during 165 minutes. During this time the total output of red blood cells in the lymph increased from $50 \times 10^{6}$ to $260 \times 10^{6}$ cells per minute. The rate of lymph flow averaged $0.9 \mathrm{ml}$ per minute. SBP suspension was infused in 20 minutes. At the end of the infusion a reduction of red blood cell output to $35 \times 10^{6}$ cells per minute $(-87$ per cent) was observed. The lymph flow increased slightly to $1.0 \mathrm{ml}$ per minute. At the end of 1 hour the red blood cell output was $48 \times 10^{6}$ cells per minute $(-82$ per cent). The blood pressure was $95 \mathrm{~mm} \mathrm{Hg}$ and the rate of lymph flow was unchanged.

Dog 34 (Figure 12). The thoracic duct of this $12.6 \mathrm{~kg}$ male dog was cannulated 5 days after irradiation, when the lymph was still free of red blood cells. The platelet count at this time was 12,000 per $\mathrm{mm}^{3}$. Six days later the lymph be- came hemorrhagic. The platelet count was 5,000 per $\mathrm{mm}^{3}$. The animal was anesthetized and six lymph samples were collected during an equilibration period of 2 hours. The total output of red blood cells in the lymph during this time increased from $372 \times 10^{6}$ to $588 \times 10^{6}$ cells per minute. Lymph flow rate averaged $0.7 \mathrm{ml}$ per minute. SBP suspension was infused in 25 minutes. Within 20 minutes from the start of the infusion the red cell output in the lymph decreased to $3 \times 10^{6}$ cells per minute and remained low for about 90 minutes. The output then increased to $266 \times 10^{6}$ cells per minute and this level was maintained with minor variations for the remaining time of observation. The lymph flow after the infusion of SBP averaged $0.5 \mathrm{ml}$ per minute. The mean arterial blood pressure remained stable at $100 \mathrm{~mm} \mathrm{Hg}$ throughout the study.

\section{DISCUSSION}

The intravenous administration of a preparation of soybean phosphatides to X-irradiated, thrombocytopenic dogs was followed by reduction of the output of red blood cells in the lymph collected from the left thoracic lymph duct. Comparison of this change to the variations occurring in a control group given isotonic saline showed a statistically significant difference $(\mathrm{p}<0.005)$. On five occasions (Dogs 18, 23, 30, 34, and 36) complete or nearly complete, although temporary, clearing of the lymph in regard to appearance and red blood cell content was observed. Marked reduction of bleeding into the lymph occurred in most of the other animals. The duration of the effects of soybean phosphatides was relatively short. The maximal reduction of bleeding into the lymph rarely persisted for longer than 2 hours after the infusion, although on some occasions (Dogs 30, 34, 36, and 55) a significant decrease was present as long as 4 to 5 hours later. Repeated administration (Dogs 55 and 57), however, was apparently again effective.

The mechanism of action of soybean phosphatides on the vascular permeability to red blood cells is not clear. A generalized reduction of the blood pressure apparently does not account for decreased diapedesis of the red cells. Determinations of the mean arterial pressure in Dogs 18. 22, and 34 did not indicate significant changes following the administration of phosphatides. 
The role of the coagulation mechanism in this phenomenon can not be evaluated adequately on the basis of the data available. Although the serum prothrombin time in 2 of the 4 animals studied was prolonged, thus suggesting an increased prothrombin consumption (5), the serum prothrombin time in the other 2 animals did not change. Extensive further studies may therefore be warranted in regard to the preparation of SBP used here to evaluate the role of blood coagulation in the maintenance of vascular integrity.

It is of interest that the prolonged bleeding time, observed in all animals studied, remained essentially unchanged even during the time of maximal reduction or arrest of bleeding into the lymph. It is possible therefore that the increased permeability of blood and lymph vessels to red blood cells and the bleeding from mechanically injured small vessels are controlled by different mechanisms. Infusion of viable platelets correct both the increased vascular permeability to red cells and the abnormal bleeding time of thrombocytopenic animals. The latter effect appears to be associated with the ability of platelets to form "hemostatic plugs," while a different, as yet unidentified function of platelets may account for maintaining the integrity of blood vessels, thus preventing the diapedesis of red blood cells. A dissociation of the changes of the bleeding time from those of vascular permeability to red blood cells also has been suggested by the frequent observation of normal lymph in animals with low platelet counts and prolonged bleeding time. Further studies to determine the mechanisms by which platelets or materials such as soybean phosphatides reduce the abnormal diapedesis of red blood cells may be of value in understanding the function of platelets in hemostasis.

It should be noted in this respect that the degree to which bleeding into the lymph was reduced by soybean phosphatides was of the same order as that observed after transfusion of fresh platelets (4). The duration of the hemostatic effects of fresh platelets, however, was considerably longer than those induced by soybean phosphatides. The onset of hemostasis, on the other hand, occurred earlier with soybean phosphatides than with platelets. The mechanism of action of the phosphatides, therefore, may be of a different nature than that of platelets.

\section{SUMMARY}

Intravenous administration of a soybean phosphatide preparation to X-irradiated, thrombocytopenic dogs was followed by rapid reduction of bleeding into the lymph of the left thoracic lymph duct. The maximal effects of a single infusion lasted 2 to 3 hours, but could be maintained or induced again by subsequent infusions. Complete return of the lymph to normal appearance and content of red blood cells was observed in some of the animals. The prolonged bleeding time was not affected.

\section{ACKNOWLEDGMENT}

The authors wish to acknowledge the help and advice of Dr. Robert B. Reed, Department of Biostatistics, Harvard School of Public Health, in the statistical analysis of the data presented in this paper.

\section{REFERENCES}

1. Bigelow, R. R., Furth, J., Woods, M. C., and Storey, R. H. Endothelial damage by X-rays disclosed by lymph fistula studies. Proc. Soc. exp. Biol. (N. Y.) 1951, 76, 734.

2. Drinker, C. K., and Yoffey, J. M. Lymphatics, Lymph and Lymphoid Tissue. Cambridge, Mass., Harvard University Press, 1941.

3. Woods, M. C., Gamble, F. N., Furth, J., and Bigelow, R. R. Control of the post-irradiation hemorrhagic state by platelet transfusions. Blood 1953, 8, 545.

4. Jackson, D. P., Sorenson, D. K., Cronkite, E. P., Bond, V. P., and Fliedner, T. M. Effectiveness of transfusions of fresh and lyophilized platelets in controlling bleeding due to thrombocytopenia. J. clin. Invest. 1959, 38, 1689.

5. White, S. G., Lagen, J. B., Aggeler, P. M., and Geyer, R. P. Effect of soybean phosphatide on blood coagulation defect following total body $\mathrm{X}$-irradiation in the dog. Proc. Soc. exp. Biol. (N. Y.) 1953, 83, 384.

6. Brown, C. S., and Hardenbergh, E. A technique for sampling lymph in unanesthetized dogs by means of an exteriorized thoracic duct-venous shunt. Surgery 1951, 29, 502.

7. Brecher, G., and Cronkite, E. P. Morphology and enumeration of platelets. J. appl. Physiol. 1950, 3, 365.

8. Alexander, B. Estimation of plasma prothrombin by the one-stage method in The Coagulation of Blood, L. Tocantins, Ed. New York, Grune and Stratton, 1955 , p. 94. 